\author{
В. М. ЛЕХАН ${ }^{1}$, К. О. НАДУТИЙ ${ }^{2}$ Л. О. ГРИЦЕНКО
}

\title{
ОЦІНКА ДІЯЛЬНОСТІ ЗАМОВНИКА МЕДИЧНИХ ПОСЛУГ КЕРІВНИКАМИ ЗАКЛАДІВ ПЕРВИННОЇ МЕДИЧНОЇ ДОПОМОГИ
}

\author{
${ }^{1}$ Дніпровський державний медичний університет, м. Дніпро, Україна \\ 2Громадська організація «Українська медична експертна спільнота», м. Буча, Україна
}

\begin{abstract}
Мета: оцінка керівниками закладів первинної медичної допомоги (ПМД) стосунків між замовником і постачальниками медичних послуг за умов запровадження в Україні програми медичних гарантій (ПМГ) та виявлення характеристик діяльності замовника, які потребують удосконалення з точки зору постачальників послуг ПМД.

Матеріали і методи. Дослідження проведено у два етапи: фокус інтерв'ювання керівників закладів ПМД 3 високим рівнем компетентності для визначення набору характеристик діяльності замовника медичних послуг; опитування за нашою анкетою, складеною за результатами першого етапу дослідження, 100 керівників закладів ПМД. Статистичний аналіз, що включав методи описової та аналітичної статистики, здійснено за допомогою STATISTICA 6.1.

Результати. Виділено 11 параметрів, які характеризують діяльність замовника медичних послуг у системі ПМД разом із загальною оцінкою його функціонування. Із загального числа опитаних негативно або скоріше негативно оцінили: збалансованість стосунків із замовником - 70 \%, порядок фрормування замовником вимог до постачальників - 70 \%, реагування замовника на зміну потреб у послугах ПМД - 21 \%, обґрунтованість тарифу для фрінансування послуг ПМД - 96 \%, фрінансову забезпеченість введення нових вимог до надавачів - $91 \%$, цілеспрямованість політики щодо формування ПМГ - $67 \%$, ефрективність ПМГ - 50 \%, дієвість економічних стимулів ПМГ - 84 \%, узгодженість намірів і дій, що потребують інвестицій, між замовником та надавачем послуг 60 \%, характеристику електронної системи охорони здоров'я - 52 \%. У цілому діяльність замовника медичних послуг 72 \% оцінили скоріше позитивно, ніж негативно, 28 \% - скоріше негативно, ніж позитивно.

Висновки. Дослідження показало існування складнощів фрормування стосунків між замовником і постачальниками послуг ПМД при реалізації реформи фрінансування системи охорони здоров'я. Встановлено, що серед характеристик діяльності замовника постачальників найбільше турбують недоліки економічної обґрунтованості та прогалини політичної урегульованості цих взаємовідносин.
\end{abstract}

КЛЮчОВІ СЛОВА: первинна медична допомога; програма медичних гарантій; замовник медичних послуг; постачальники медичних послуг.

За матеріалами ВООЗ, ефективність боротьби з хронічними неінфекційними захворюваннями і збільшення соціальної справедливості стосовно питань охорони здоров'я залежать від співробітництва громадської охорони здоров'я та системи первинної медичної допомоги (ПМД) [5]. Також існують переконливі дані, що сильна ПМД тісно пов'язана 3 поліпшенням стану здоров'я населення, більш низькими показниками запобіжних госпіталізацій і відносно низьким рівнем соціально-економічної нерівності [8, 9]. У період епідемії COVID-19 поширюється підтримана ВООЗ інформація, що ПМД відіграє найважливішу роль у підвищенні життєстійкості системи охорони здоров'я за умов кризових ситуацій, забезпечення їх готовності до оперативного вжиття заходів у разі різкого підвищення попиту на послуги охорони здоров'я [7].

В Україні з 2018 р. відбувається реформування фрінансування системи охорони здоров'я, в тому числі ПМД як її складової, яке спрямоване на зміцнення системи і включає впровадження державного гарантованого пакета медичної допомоги, створення єдиного національного замовника медичних послуг, автономізацію постачальників медичної допомоги, нові методи оплати та нову

( В. М. Лехан, К. О. Надутий, Л. О. Гриценко, 2021 систему управління якістю послуг [2, 3]. Проведення таких кардинальних перетворень завжди стикається 3 певними проблемами і потребує знаходження консенсусу між замовником, яким виступає Національна служба здоров'я України, і постачальниками медичних послуг.

Мета дослідження: оцінка керівниками закладів ПМД стосунків між замовником і постачальниками медичних послуг за умов запровадження в Україні програми медичних гарантій та виявлення характеристик діяльності замовника, які потребують удосконалення з точки зору постачальника послуг ПМД.

Матеріали і методи. Дослідження проведено у два етапи. На першому етапі визначали набір характеристик діяльності замовника медичних послуг у системі ПМД, на другому - проводили їх оцінку. Перший етап реалізовували зі застосуванням методу фокус-інтерв'ю. За даними внутрішніх соціологічних опитувань, які проводила Українська асоціація сімейної медицини (УАСМ), виявляли характеристики замовника послуг ПМД, на які звертали увагу члени асоціації. Далі проведено 2-турове інтерв'ювання дистанційної фокус-групи чисельністю 10 осіб, сформованої з числа керівників закладів ПМД з високим рівнем компетентності. Групою 3 трьох експертів 
проведено градуювання шкал для вимірювання різних характеристик, розроблено і представлено у вигляді Google Форми анкету «Оцінка діяльності замовника послуг ПМД». На другому етапі у дистанційному режимі через УАСМ проводили анкетування керівників закладів ПМД. Усього в опитуванні взяло участь 100 осіб, що при чисельності генеральної сукупності 1057 закладів ПМД $\epsilon$ репрезентативною вибіркою (необхідна розрахункова чисельність вибірки 89 одиниць).

Серед залучених керівників більшість у віці до 60 років (91 \%, $95 \%$ ДІ 85-97), у тому числі $38 \%$ (95 \% ДІ 28-48) до 45 років; зі стажем роботи на керівній посаді до 10 років - 69 \% (95\% ДІ 6078); мають сертифрікат з організації та управління охороною здоров'я - 81 \% (95 \% ДІ 73-89); працюють в закладах, розташованих у сільській місцевості, $40 \%$ (95\% ДІ 30-50), в містах - $60 \%$ (95\% ДІ 50-70), у тому числі в малих - $25 \%$ (95 \% ДІ 17-33), у середніх - 9 \% (95 \% ДІ 3-15), у великих - $14 \%$ (95\% ДІ 7-21), в надвеликих і найбільших містах - 12 \% (95 \% ДІ 6-18).
Статистичну обробку результатів проводили за допомогою програмного продукту STATISTICA 6.1 (StatSoftlnc., серійний № AGAR909E415822FA). Для оцінки результатів дослідження використовували методи описової та аналітичної статистики. Для відносних величин розраховували $95 \%$ довірчі інтервали (95 \% ДІ) за відкоригованим методом Вальда. Оцінку достовірності відмінностей відносних показників проводили за критерієм Хі-квадрат Пірсона (Chi-square test $-\chi^{2}$ ). Оцінку зв'язків між змінними здійснювали за допомогою рангового кореляційного аналізу з розрахунком коефіцієнтів кореляції Спірмена $\left(\mathrm{r}_{\mathrm{s}}\right)$, множинного кореляційного аналізу (R). Критичне значення рівня статистичної значущості для всіх видів аналізу приймали на рівні $р<0,05$. Для розподілу змінних на відносно однорідні групи застосовували метод кластерного аналізу.

Результати дослідження та їх обговорення. На першому етапі дослідження виділено 11 параметрів, які характеризують діяльність замовника медичних послуг у системі ПМД з узагальненою оцінкою фрункціонування замовника (табл. 1).

Таблиця 1. Характеристики діяльності замовника медичних послуг у системі первинної медичної допомоги

\begin{tabular}{|l|c|c|}
\hline \multicolumn{1}{|c|}{ Найменування } & Тип змінної & $\begin{array}{c}\text { Умовна } \\
\text { позначка }\end{array}$ \\
\hline Збалансованість стосунків між замовником та надавачами послуг & Не залежна & $\mathrm{x}_{1}$ \\
\hline Порядок фрормування замовником вимог до постачальників & Не залежна & $\mathrm{x}_{2}$ \\
\hline Реагування замовника на зміни потреб у послугах & Не залежна & $\mathrm{x}_{3}$ \\
\hline Обгрунтованість тарифу (капітаційної ставки) для фрінансування послуг & Не залежна & $\mathrm{x}_{4}$ \\
\hline Фінансова забезпеченість введення нових вимог до надавачів & Не залежна & $\mathrm{x}_{5}$ \\
\hline Цілеспрямованість політики щодо фрормування програми медичних гарантій & Не залежна & $\mathrm{x}_{6}$ \\
\hline Ефективність програми медичних гарантій & Не залежна & $\mathrm{x}_{7}$ \\
\hline Дієвість економічних стимулів програми медичних гарантій & Не залежна & $\mathrm{x}_{8}$ \\
\hline $\begin{array}{l}\text { Узгодженість намірів і дій, що потребують інвестицій, між замовником та } \\
\text { надавачами послуг }\end{array}$ & Не залежна & $\mathrm{x}_{9}$ \\
\hline Характеристика електронної системи охорони здоров'я & Не залежна & $\mathrm{x}_{10}$ \\
\hline Загальна оцінка діяльності замовника послуг & Залежна & $\mathrm{x}_{11}$ \\
\hline
\end{tabular}

Узагальнену оцінку різних характеристик діяльності замовника медичних послуг керівниками закладів ПМД наведено на рисунку 1.

Стосунки із замовником медичних послуг НСзУ $\left(\mathrm{x}_{1}\right)$ оцінили як партнерські, коли замовник вивчає думку постачальників та веде з ними заінтересований діалог, - лише 28 \%. Більшість (70 \%) охарактеризувала їх як недостатньо (43\%), погано збалансованими (11 \%) або незбалансованими (16 \%), коли замовника мало цікавить або взагалі не цікавить думка постачальників ПМД.

Економічну і технічну обґрунтованість вимог замовника на основі взаємних домовленостей і 3 урахуванням можливостей постачальників $\left(\mathrm{x}_{2}\right)$ позитивно оцінили ледь більше 1/5 опитаних (21 \%), а $70 \%$ вважають, що вимоги до постачальників послуг часто (46 \%) або завжди (24 \%) формуються без чіткого обґрунтування та врахування можливостей постачальників:

Із загального числа опитаних керівників $70 \%$ зазначили, що НСЗУ реагує на зміну потреб населення в медичній допомозі $\left(\mathrm{x}_{3}\right)$, у тому числі завжди адекватно і своєчасно - $16 \%$, інколи адекватно і своєчасно - $54 \%$. Проте кожний п'ятий респондент (21 \%) відзначив, що замовник на зміну потреб не реагує або реагує невчасно і неадекватно.

Унормовану оплату на душу населення послуг ПМД (капітаційну ставку) добре обґрунтованою і такою, що покриває потреби населення в ПМД $\left(\mathrm{x}_{4}\right)$, вважає лише 2 \% опитаних; більшість (96 \%) оцінила її як недостатньо обґрунтовану або цілком необґрунтовану. 


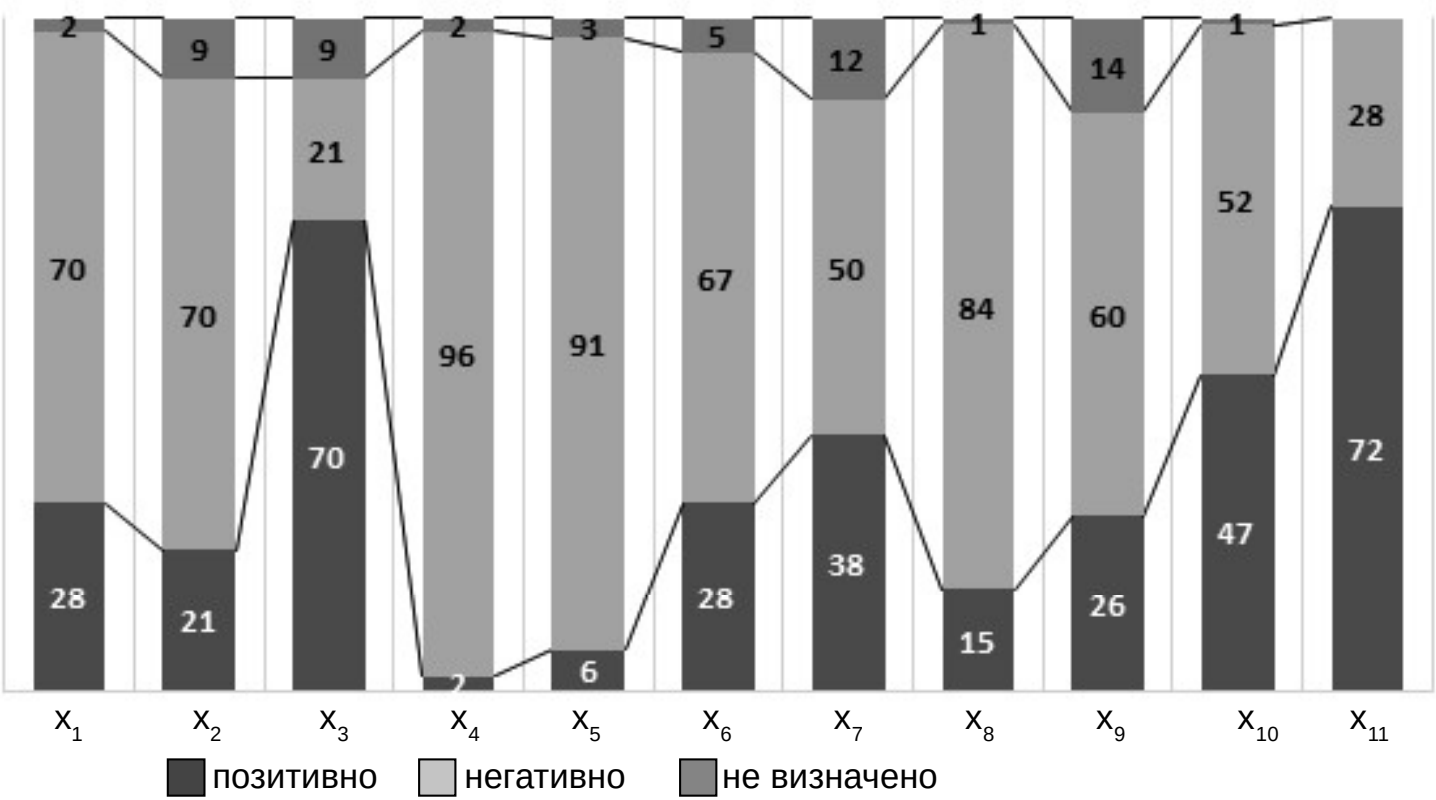

Puc. 1. Узагальнена оцінка характеристик діяльності замовника (за результатами опитування керівників закладів первинної медичної допомоги).

Примітка: значення позначок $\mathrm{x}_{1}-\mathrm{x}_{11}$ див. у таблиці 1 .

Періодичне оновлення вимог до надавачів ПМД у середовищі, яке постійно змінюється, є необхідним. Проте для забезпечення реалізації нових вимог потрібні чіткі розрахунки та визначення джерел орінансування для їх покриття. Практично всі опитані (91 \%) вважають, що нові вимоги до надавачів ПМД, які потребують додаткових інвестицій $\left(\mathrm{x}_{5}\right)$, вводять без підкріплення реальним фрінансуванням. Про узгодження замовником своїх намірів та дій, які потребують додаткових витрат, 3 громадами-власниками закладів ПМД $\left(\mathrm{x}_{9}\right)$ заявили $26 \%$ респондентів (завжди - $13 \%$; іноді - 13 \%), а 60 \% зазначили, що така взаємодія взагалі не відбувається.

Одним із найвагоміших аргументів прийняття Закону «Про державні фрінансові гарантії надання медичних послуг» було те, що його реалізація забезпечить підвищення якості та доступності медичної допомоги в цілому, й ПМД зокрема [1]. Для досягнення поставлених цілей необхідна чітка політична спрямованість при фрормуванні ПМГ. Із загального числа опитаних керівників закладів ПМД майже третина (28 \%) відзначила, що політика формування ПМГ $\left(\mathrm{x}_{6}\right)$ сприяє покращенню якості та доступності ПМД населенню; водночас $67 \%$ заявили, що політика, яка реалізується замовником, мало сприяє (47\%) або навіть призводить до зменшення (20 \%) якості та доступності ПМД.

На сучасному етапі розвитку вважається доведеним, що сильна ПМД сприяє підвищенню ефективності використання ресурсів системи охорони здоров'я, насамперед через зменшення потреб у госпітальній та екстреній медичній допомозі $[4,6,9]$. На питання «Чи сприяє реалізація програми медичних гарантій поліпшенню утилізації послуг охорони здоров'я» $\left(\mathrm{x}_{7}\right) 38$ \% респондентів відповіли, що ПМГ сприяє зменшенню використання послуг екстреної і спеціалізованої (амбулаторної і стаціонарної), а 50 \% констатували, що ПМГ мало (40 \%) або зовсім (10\%) не впливає на раціоналізацію споживання медичних послуг. Звичайно до певної поведінки надавачів послуг підштовхують певні стимули, перш за все економічні. 15 \% опитаних назвали дієвими застосовувані при реалізації ПМГ економічні стимули, які сприяють розкриттю потенціалу ПМД щодо первинної і вторинної профрілактики захворювань та впливають на здоров'я пацієнтів і утилізацію послуг госпітального сектору $\left(\mathrm{x}_{8}\right)$, 59 \% - недостатньо дієвими, а 25 \% заявили, що такі стимули взагалі відсутні.

Невід'ємною складовою реалізації ПМГ $\epsilon$ фрункціонування електронної системи охорони здоров'я (ЕСО3). При оцінці роботи ЕСО3 $\left(\mathrm{x}_{10}\right)$ управлінці розділилися практично навпіл: $47 \%$ оцінили позитивно, незважаючи на періодичні збої в її роботі, 52 \% - негативно, зазначивши, що часто виникають проблеми, які заважають роботі закладу.

У цілому діяльність замовника медичних послуг $\left(\mathrm{x}_{11}\right) 72 \%$ оцінили скоріше позитивно, ніж негативно, $28 \%$ - скоріше негативно, ніж позитивно.

Дані кореляційного аналізу свідчать про те, що всі характеристики, окрім ефективності ПМГ, мають достовірний середньої сили або слабкий зв'язок із загальною оцінкою діяльності замовника (рис. 2). Множинний коефіцієнт кореляції складає $\mathrm{R}=0,79$ ( $\mathrm{p}<0,0001)$, коефріцієнт детермінації $\mathrm{R}^{2}=0,62$, тобто на $62 \%$ оцінка діяльності замовника залежить від комплексу його характеристик, які включені в дослідження.

Оцінка діяльності замовника практично не залежить від характеристик опитуваних - за рівнем управлінської підготовки, стажем, місцевістю, в якій працює керівник. Виявлено слабкий від'ємний зв'язок $(r=-0,28 ; p<0,05)$ з віком респон- 


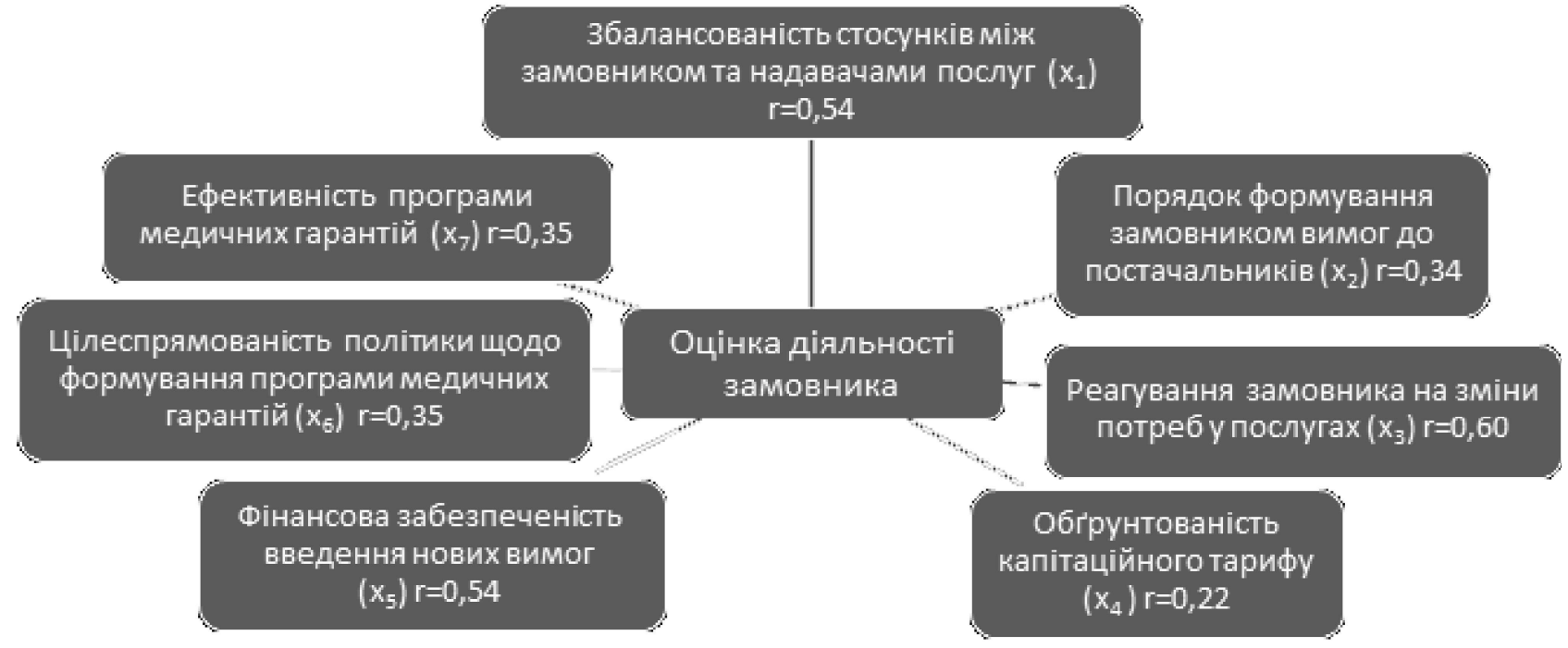

Puc. 2. Кореляційні зв'язки між окремими характеристиками та загальною оцінкою діяльності замовника послуг пМД у цілому.

дентів, тобто молодші керівники дещо позитивніше ставляться до діяльності замовника.

Проведений кластерний аналіз характеристик діяльності замовника послуг ПМД дозволив виявити два достатньо чітких кластери (рис. 3). Перший кластер, умовно названий економічним, об'єднує три характеристики: обґрунтованість тарифру для фрінансування послуг $\left(\mathrm{x}_{4}\right)$ та фрінансову забезпеченість введення нових вимог до надавачів $\left(\mathrm{x}_{5}\right)$, між якими найменша евклідова відстань, до яких логічно приєднується дієвість економіч- них стимулів програми медичних гарантій $\left(\mathrm{x}_{8}\right)$. Другий кластер, умовно названий політичним, включає дві характеристики: цілеспрямованість політики щодо формування програми медичних гарантій $\left(\mathrm{x}_{6}\right)$ та есрективність програми медичних гарантій $\left(x_{7}\right)$. Інші характеристики, особливо реагування замовника на зміни потреб у послугах $\left(\mathrm{x}_{3}\right)$ та характеристика електронної системи охорони здоров'я $\left(\mathrm{x}_{10}\right)$, мають значну евклідову відстань, тобто виступають у цій сукупності як відносно відокремлені чинники.

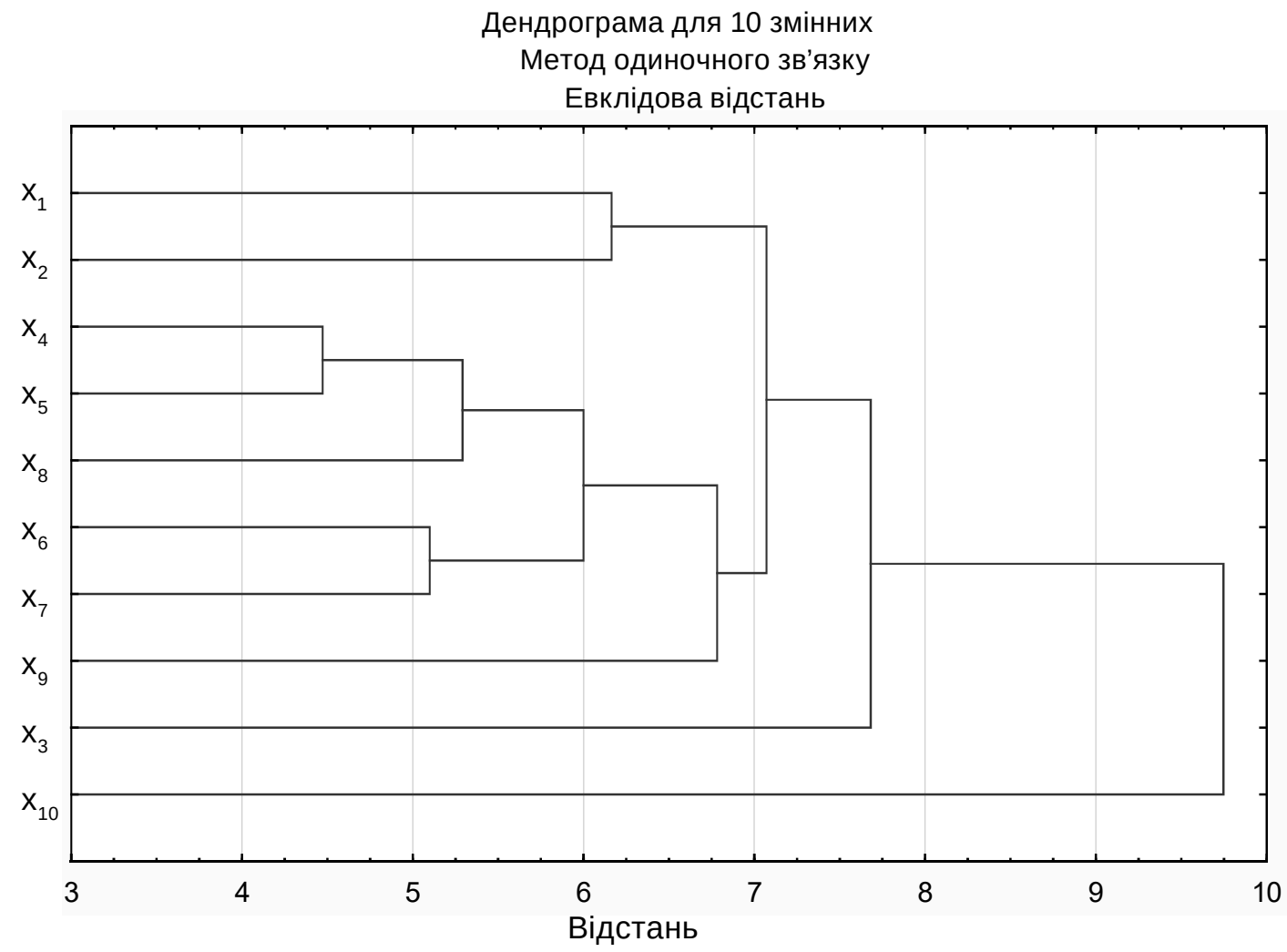

Puc. 3. Кластерний аналіз (дендрограма) для характеристик діяльності замовника послуг. Примітка: значення позначок $\mathrm{x}_{1}-\mathrm{x}_{10}$ див. у таблиці 1. 
Таким чином, економічна та політична компоненти в основному характеризують діяльність замовника послуг ПМД.

Керівники закладів ПМД висловили низку пропозицій, спрямованих на поліпшення стосунків із замовником медичних послуг. Найчастіше рекомендували: нормативне забезпечення обов'язковості та публічності процесу економічного обґрунтування капітаційної ставки - 58 \% (95 \% ДІ 48-68) опитаних; законодавче врегулювання балансу повноважень замовника і надавачів послуг 43 \% (95 \% ДІ 33-53) та відповідальності замовника за доступність і якість медичної допомоги населенню 42 \% (95 \% ДІ 32-52); врегулювання обов'язковості публічного обговорення рішень, що впливають на діяльність закладів
ПМД, та врахування його результатів у практичній площині 42 \% (95 \% ДІ 32-52).

\section{Висновки}

Дослідження показало існування складнощів фрормування стосунків між замовником і постачальниками послуг ПМД при реалізації реформи фрінансування системи охорони здоров'я. Встановлено, що серед характеристик діяльності замовника медичних послуг постачальників найбільше турбують недоліки економічної обґрунтованості та прогалини політичної урегульованості цих взаємовідносин.

Перспективи подальших досліджень полягають у вивченні ефективності стосунків постачальників ПМД 3 органами місцевого самоврядування, від якої також залежать якість та доступність ПМД.

\section{Список літератури}

1. Пояснювальна записка до проекту Закону про державні фрінансові гарантії надання медичних послуг та лікарських засобів [Електронний ресурс]. - Режим доступу : http://w1.c1.rada.gov.ua/pls/zweb2/webproc4_2?pf3516= $6327 \& s k l=9$.

2. Про державні фрінансові гарантії медичного обслуговування населення : Закон України від 19 жовтня 2017 р. № 2168-VIII [Електронний ресурс]. - Режим доступу : https://zakon.rada.gov.ua/laws/show/2168-19\#Text.

3. Про схвалення Концепції реформи фрінансування системи охорони здоров'я : Розпорядження Кабінету Міністрів України від 30 листопада 2016 р. № 1013-р. [Електронний ресурс]. - Режим доступу : https://zakon.rada.gov.ua/laws/ show/1013-2016-\%D1\%80\#Text.

4. Assessing health services delivery performance with hospitalizations for ambulatory care sensitive conditions. World Health Organization. WHO Regional Offce for Europe: Copenhagen, 2016. 43 p.

5. Ensuring collaboration between primary health care and public health services / World Health Organization. Copenhagen: WHO Regional Office for Europe, 2018. 40 p.

6. Estimates of potentially preventable hospitalizations for ambulatory care sensitive conditions in Ukraine / V. N. Lekhan, L. V. Kriachkova, O. O. Doroshenko, L. O. Gritsenko // Medicni perspektivi. - 2020. - № 4. - P. 189-198. DOI: https://doi. org/10.26641/2307-0404.2020.4.221711

7. Primary health care. World Health Organization, 2021. Режим доступу: https://www.who.int/news-room/fact-sheets/ detail/primary-health-care

8. Report of the Global Conference on Primary Health Care: From Alma-Ata towards Universal Health Coverage and the Sustainable Development Goals / World Health Organization. Geneva: WHO, 2019. - 74 p.

9. Strengthening people-centred health systems: a European framework for action on integrated health service delivery. Copenhagen: WHO Regional Office for Europe, 2016. - 43 p.

\section{References}

1. (2017). Poiasniuvalna zapyska do proektu Zakonu pro derzhavni finansovi harantii nadannia medychnykh posluh ta likarskykh zasobiv. [Explanatory note to the draft Law on State Financial Guarantees for the Provision of Medical Services and Medicines]. Retrieved from: http://w1.c1.rada.gov.ua/pls/zweb2/webproc4_2?pf3516=6327\&skl=9 [in Ukrainian].

2. (2017). Zakon Ukrayiny Pro derzhavni finansovi harantii medychnoho obsluhovuvannia naselennia vid 19 zhovtnia 2017 roku № 2168-VIII. [Law of Ukraine About the state financial guarantees of medical service of the population of Oktober 19, 2017 No. 2168-VIII]. zakon.rada.gov.ua Retrieved from: https://zakon.rada.gov.ua/laws/show/2168-19\#Text [in Ukrainian].

3. (2016). Rozporiadzhennia KMU vid 30 lystopada 2016 r. № 1013-r. «Pro skhvalennia Kontseptsii reformy finansuvannia systemy okhorony zdorovia» [Order of the Cabinet of Ministers of Ukraine of November 30, 2016 No. 1013-r. About the approval of the Concept of health care financing reform]. zakon.rada.gov.ua Retrieved from: https://zakon.rada.gov.ua/ laws/show/1013-2016-\%D1\%80\#Text [in Ukrainian].

4. (2016). Assessing health services delivery performance with hospitalizations for ambulatory care sensitive conditions Copenhagen. World Health Organization. WHO Regional Offce for Europe.

5. (2018). Ensuring collaboration between primary health care and public health services. World Health Organization. WHO Regional Office for Europe Copenhagen.

6. Lekhan, V.N., Kriachkova, L.V., Doroshenko, O.O., \& Gritsenko, L.O. (2020). Estimates of potentially preventable hospitalizations for ambulatory care sensitive conditions in Ukraine. Medicni perspektivi, 25(4), 189-198. Doi: https://doi. org/10.26641/2307-0404.2020.4.221711

7. (2021). Primary health care. World Health Organization. www.who.int Retrieved from: https://www.who.int/news-room/ fact-sheets/detail/primary-health-care 
8. (2019). Report of the Global Conference on Primary Health Care: From Alma-Ata towards Universal Health Coverage and the Sustainable Development Goals. World Health Organization. Geneva: WHO.

9. (2016). Strengthening people-centred health systems: a European framework for action on integrated health service delivery. WHO Regional Office for Europe. Copenhagen.

\section{ASSESSMENT OF THE ACTIVITIES OF THE PURCHASER OF MEDICAL SERVICES BY THE HEADS OF PRIMARY HEALTH CARE FACILITIES}

V. M. Lekhan ${ }^{1}$, K. O. Nadutiy ${ }^{2}$, L. O. Gritsenko ${ }^{1}$

${ }^{1}$ Dnipro State Medical University, Dnipro, Ukraine

2Public organization "Ukrainian Medical Expert Community", Bucha, Ukraine

Purpose: to assess the relationship between the Purchaser and medical service providers in the conditions of introduction of the medical guarantee program (MGP) in Ukraine and to identify the characteristics of the Purchaser 's activities that need improvement in terms of primary care providers.

Materials and Methods: The study was conducted in two stages: the focus of interviewing the heads of primary care facilities with a high level of competence to determine a set of characteristics of the Purchaser of medical services; survey according to our questionnaire, compiled based on the results of the first stage of the study, 100 heads of primary care facilities. Statistical analysis, including methods of descriptive and analytical statistics, was performed using STATISTICA 6.1.

Results. 11 parameters were identified that characterize the activity of the Purchaser of medical services in the PHC system together with the generalized assessment of the Purchaser's functioning. Of the total number of respondents negatively or rather negatively assessed: the balance of relations with the Purchaser - $70 \%$, the order of formation of the Purchaser's requirements for suppliers - $70 \%$, the Purchaser's response to changing needs for PHC services $-21 \%$, the reasonableness of the tariff for financing PHC services - $96 \%$, financial security of introduction of new requirements to providers $-91 \%$, purposefulness of policy on formation of MGP $67 \%$, efficiency of MGP - $50 \%$, efficiency of economic incentives of MGP - $84 \%$, coordination of intentions and actions requiring investments between the Purchaser and the service provider $-60 \%$, characteristics of the electronic health care system $-52 \%$. In general, $72 \%$ rated the activity of the Purchaser of medical services positively rather than negatively, $28 \%$ - negatively rather than positively.

Conclusions. The study showed the existence of difficulties in forming a relationship between the Purchaser and providers of PHC services in the implementation of health care financing reform. It is established that among the characteristics of the Purchaser 's activity the suppliers are most concerned about the shortcomings of economic validity and gaps in the political settlement of these relationships.

KEY WORDS: primary health care; medical guarantees program; Purchaser of medical services; providers of medical services.

Рукопис надійшов до редакції 21.07.2021 p.

\section{Відомості про авторів:}

Лехан Валерія Микитівна - доктор медичних наук, профресор, профресор кафедри соціальної медицини, громадського здоров'я та управління охороною здоров'я Дніпровського державного медичного університету; тел.: +38(067) 713-71-18.

Надутий Костянтин Олександрович - член координаційної ради Громадської організації «Українська медична експертна спільнота»; тел.: +38(095) 723-89-72.

Гриценко Людмила Олександрівна - викладач кафедри соціальної медицини, громадського здоров'я та управління охороною здоров'я Дніпровського державного медичного університету; тел.: +38(067) 713-71-18. 